\title{
DVA OPEVNĚNÉ OBJEKTY U BERNARTIC (OKRES PÍSEK). K OTÁZCE JEJICH VZTAHU, FUNKČNÍ INTERPRETACE A SOUVISLOSTÍ
}

\author{
ZLATA GERSDORFOVÁ - JOSEF HLOŽEK - PETR MENŠÍK - MILAN PROCHÁZKA
}

\begin{abstract}
Abstrakt: Dva zaniklé opevněné objekty na katastru obce Borovany, okr. Pisek, představují cenné archeologické lokality založené v obdobi samého počátku budováni vrcholně středověkých opevněných objektů $v$ Čechách. Obě lokality, jejichž počátky pravděpodobně spadají do doby kolem poloviny 13. století, patrně predstavovaly $v$ době své existence nejen možné kolonizačni opory, ale také objekty založené v mistě předpokládané majetkoprávni hranice mezi državami milevského kláštera a šlechty.
\end{abstract}

Klíčová slova: hrad-kolonizace-13. století-fortifikace-těžba.

Two Fortified Features near Bernartice (Písek District). Their Relationship, Function Interpretation and Relations

Abstract: Two defunct fortified features in the cadastral zone of the village of Borovany, Pisek district, present valuable archaeological sites, established at the very outset of the building of high medieval fortified constructions in Bohemia. Both these locations, the origins of which probably go back to the mid-13th century, possibly represented in the course of their existence not only colonization footholds but also constructions founded on the presumed property and legal border between the holdings of the Milevsko monastery and the aristocracy.

Key words: castle - colonization - 13th century-fortification-mining

Úvod

V historické a archeologické literatuře jsou uváděna dvě „feudální sídla“ (obr. 1, 4 a 5) nacházející se ve vzdálenosti 2,3 km jižně od obce Bernartice na Písecku, nedaleko kaple sv. Rozálie na katastru obce Borovany. V roce 2014 byl realizován povrchový průzkum lokalit s cílem revize dosavadní plánové dokumentace a interpretace obou objektů. Při interpretaci obou lokalit

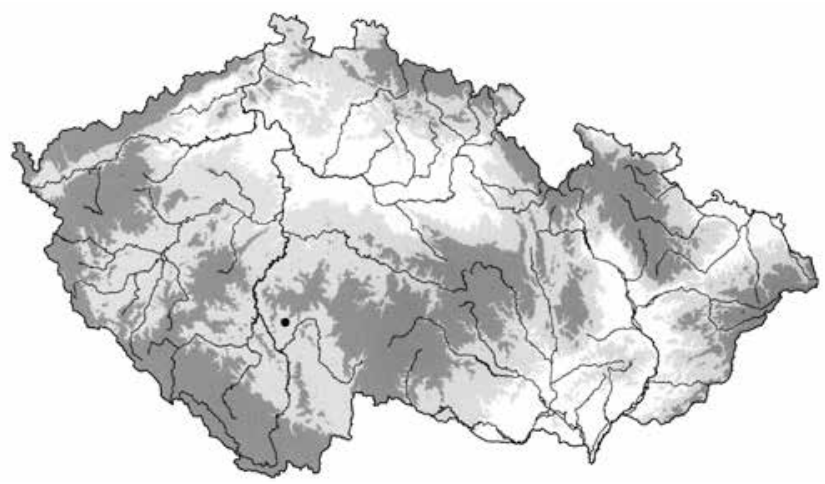

Obr. 1. Borovany u Bernartic, okr. Písek. Lokalizace dvou opevněných sídel 1, 2 na katastru obce. Vytvořil P. Menšík.

Abb. 1. Borovany u Bernartic, Bez. Písek. Lokalisierung der zwei befestigten Sitze 1, 2 im Gemeindekataster. Erstellt von P. Menšík.

bylo využito nejen nově pořízených geodetických dat, ale také výsledků leteckého laserového skenování (DGMR-5; k jeho využití v archeologii např. Gojda-John a kol. 2013). Větší z obou opevněných objektů u Bernartic je zaznamenán také na II. a III. vojenském mapování, kde je rámcově zachycen průběh mohutného obvodového prŕíkopu a valového tělesa (obr. 2 a 3 ). 


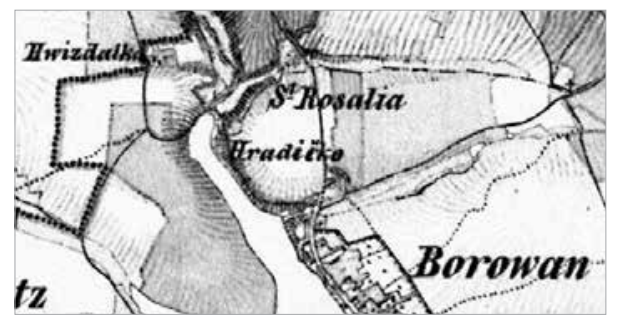

Obr. 2. Borovany u Bernartic, okr. Písek. Sledované území na výřezu mapy II. vojenského mapování.

Abb. 2. Borovany u Bernartic, Bez. Písek. Das untersuchte Gebiet in dem Ausschnitt einer Karte der II. militärischen Kartierung.

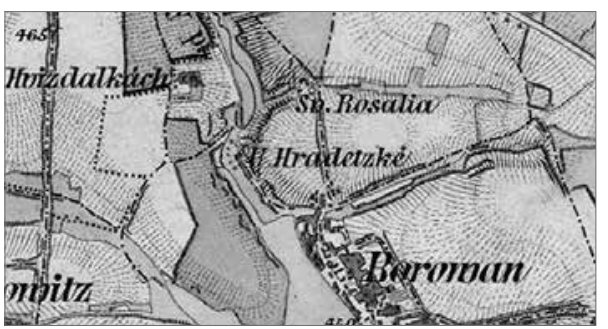

Obr. 3. Borovany u Bernartic, okr. Písek. Sledované území na výřezu mapy III. vojenského mapování.

Abb. 3. Borovany u Bernartic, Bez. Písek. Das untersuchte Gebiet in dem Ausschnitt einer Karte der III. militärischen Kartierung.

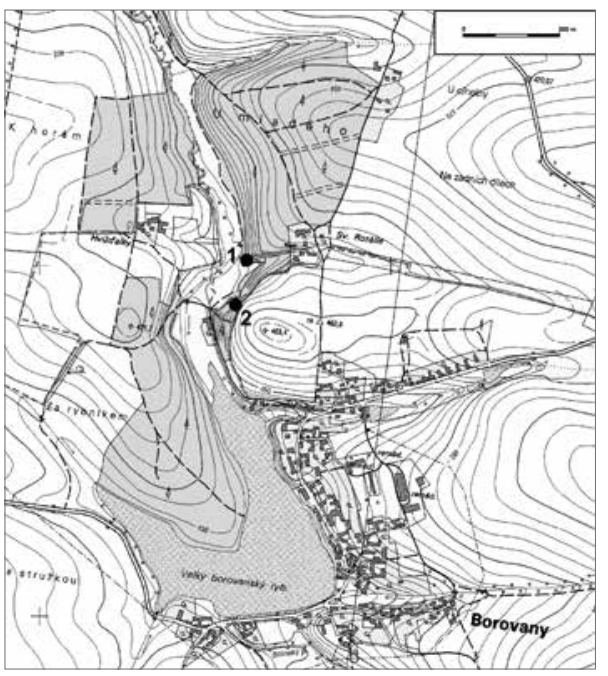

Obr. 4. Borovany u Bernartic, okr. Písek. Lokalizace dvou referovaných opevněných sídel 1,2 na mapě $1: 10000$. Vytvořil P. Menšík.

Abb. 4. Borovany u Bernartic, Bez. Písek. Lokalisierung der zwei erörterten befestigten Sitze 1, 2 auf einer Karte 1:10 000. Erstellt von P. Menšík.

mě úzkého komunikačně vytíženého nádvoří, vyplnila většinu plochy opevněného centrální objekt, plnící také nejspíše jistou formu funkce obytné, dnes představuje konvexní terénní útvar tvořený hlinitým sedimentem s nezanedbatelným podílem mazanice a lomového ka-

\section{Poloha opevněných lokalit a jejich podoba}

Asi 180 metrů jihozápadně od kaple sv. Rozálie se nachází úzká skalnatá ostrožna nazývaná od 16. století „Na hrádku“ (obr. 4:1 a 5:1). Ostroh je možné lokalizovat na mapě ZM10 22-42-01 prostřednictvím koordinát 439:226, na parc. č. 493 v nadmořské výšce 440-442 metrů. Na úzkém ostrohu vybíhajícím nad širokou nivu Bílinského potoka jsou dochovány terénní relikty nevelkého opevněného areálu (obr. 6) zaujímajícího plochu o rozměrech $6 \times 15$ metrů. Nevelký opevněný objekt byl na severní přístupové straně chráněn šíjovým příkopem (obr. 7), před jehož vnější hranou bylo navršeno dnes rozplavené valové těleso. Na západní, jižní a východní straně tvořily dostatečnou ochranu strmé skalnaté stěny zvoleného staveniště, jehož pochozí úroveň převyšovala niveletu potoční nivy o $6-8 \mathrm{~m}$. Volba pouze $\mathrm{z}$ jedné strany přístupného skalnatého ostrohu umožnila minimalizování nároků kladených na rozsah obvodového opevnění, které mělo spíše lehčí, nejspíše dřevěnou či dřevohlinitou podobu. Tíha obrany objektu spočívala především na šíjovém př́ikopu oddělujícím staveniště fortifikace od okolního terénu a valu navršeném před jeho vnější hranou (obr. 5). Komunikační schéma opevněného areálu je $\mathrm{s}$ ohledem na charakter staveniště zřejmé. Př́ístupová komunikace byla vedena od severu po mostě situovaném ve východní části šíjového př́íkopu. Jeho vnitřní opěru je možné předpokládat v místě nevýrazného snížení patrného na východní hraně eskarpy př́kopu. Po jeho překonání vstupoval příchozí branou prozatím neznámé podoby do úzkého nádvoří. Spíše než věžovité či jiné branské stavení je zde možné předpokládat $\mathrm{s}$ větší mírou pravděpodobnosti jednoduchou, např. kulisovou bránu prolamující lehčí obvodové opevnění. Východní a západní vyústění šíjového př́íkopu patrně nebylo nikterak zajištěno.

Velmi stísněné opevněné ploše dominovala pravoúhlá nepodsklepená, spíše věžovitá stavba o rozměrech ca $4,5 \times 4 \mathrm{~m}$ vystavěná $\mathrm{s}$ prrevahou dřevohlinitých konstrukcí $\mathrm{v}$ severozápadní části opevněné plochy, která, kro-

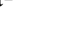




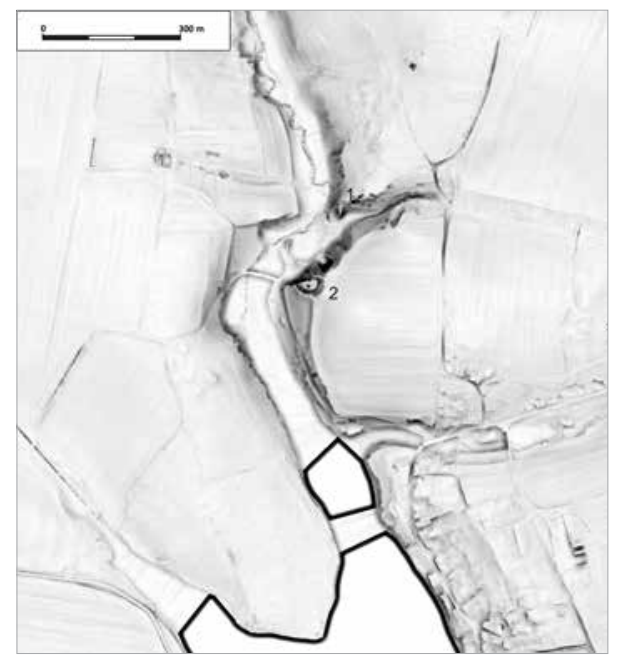

Obr. 5. Borovany u Bernartic, okr. Písek. Vizualizace dvou referovaných opevněných sídel 1, 2 na základě tzv. Digitálního modelu terénu 5. generace DMR5G. Vytvořil P. Menšík.

Abb. 5. Borovany u Bernartic, Bez. Písek. Visualisierung der zwei erörterten befestigten Sitze 1, 2 nach der Vorlage eines sog. Digitalen Geländemodells der 5. Generation DMR5G. Erstellt von P. Menšík.

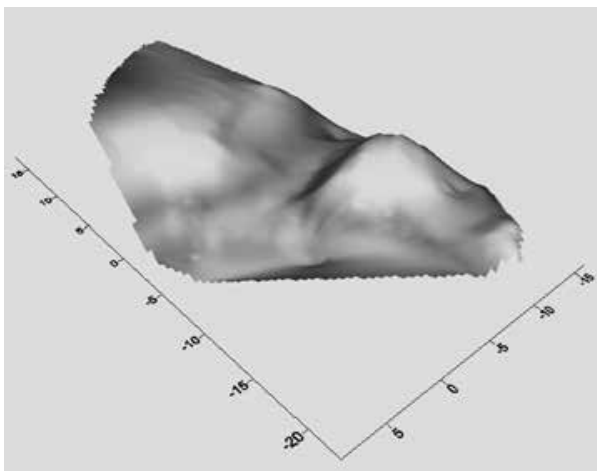

Obr. 6. Borovany u Bernartic, okr. Písek. Vizualizace opevněného sídla 1 na základě měření pomocí totální stanice. Vytvořil J. Hložek v programu Surfer 10.

Abb. 6. Borovany u Bernartic, Bez. Písek. Visualisierung des befestigten Sitzes 1 auf Grundlage der Vermessung mit einer Totalstation. Erstellt von J. Hložek mit der Software Surfer 10. mene. S ohledem na průběh terénního reliéfu nelze vyloučit, že stavba mohla být založena na skalním výchozu, jehož povrch převyšoval výškovou úroveň nádvoří. Nalezené množství lomového kamene odpovídá svým množstvím spíše zaniklým podezdívkám tvořícím základové patrie centrální věžovité stavby. Převažujícímu použití hlínou omazaných dřevěných konstrukcí při výstavbě objektu odpovídá značné množství silně přepálené mazanice vyskytující se v připovrchových partiích historického nadloží lokality i ve svahu pod sledovaným objektem. Na zánik objektu požárem ukazuje také př́ítomnost přepáleného horninového materiálu v prostoru opevněného areálu a při patě jeho staveniště. Ve svahu ostrohu pod zaniklým opevněným objektem byl při povrchovém průzkumu v roce 2014 nalezen fragment silně přepáleného silnostěnného keramického tvaru, patrně tyglíku.

Druhá zaniklá stř̌edověká fortifikace (obr. 1, 4:2, 5:2 a 9) byla založena na terénní hraně údolí Bílinského potoka asi 280 metrů jihozápadně od kaple sv. Rozálie. Místo je možné lokalizovat na mapě ZM10 22-42-01 pomocí koordinát 445:231, na parc. č. 494/2-3 v nadmořské výšce 446-450m. Opevněná plocha nepravidelného oválného půdorysu o rozměrech $35 \times 19 \mathrm{~m}$ byla ze tři př́istupných stran zajištěna výrazným, místy až čtyři metry hlubokým příkopem, před jehož vnější hranou bylo navršeno mohutné valové těleso (obr. 8, 9 a 10). Tato fortifikace byla považována v době vzniku objektu za plně dostačující, a to i za situace, kdy doširoka se rozprostírající předpolí objektu na jeho východní, patrně př́stupové straně (viz obr. 4:2, 5:2 a 9) bylo situováno o 2-4 m výše oproti pochozí úrovni opevněné plochy. Možné další zajištění dlouhodobě zemědělsky využívaného předpolí lokality nelze zcela vyloučit, ale s ohledem na předpokládanou dobu vzniku a období života tohoto objektu je existence dalších fortifikací v tomto prostoru spíše méně pravděpodobná. Charakteru terénní konfigurace staveniště sledované fortifikace odpovídá průběh obvodového př́ikopu, který dosahuje největších rozměrů na východní straně lokality, kde by bylo také možné, s nezbytnou mírou opatrnosti, předpokládat dnes zaniklou př́ístupovou komunikaci. Na západní straně lokality, směrem k severozápadnímu a jihozápadnímu vyústění, se obvodový př́íkop poněkud zužuje a nedosahuje takové hloubky jako v prostoru předpokládaného čela opevněného areálu. Tato skutečnost však může být způsobena nejen nižším nárokem kladeným na tuto část obvodové fortifikace situované nad říčním údolím, ale také možnou kumulací splachového materiálu z rozplavovaného valového tělesa navršeného před vnější hranou př́ikopu i erozí vnitřní opevněné plochy. Ve stř̌ední části jižního průběhu př́ikopu je dnes patrný zemní násep umožňu- 


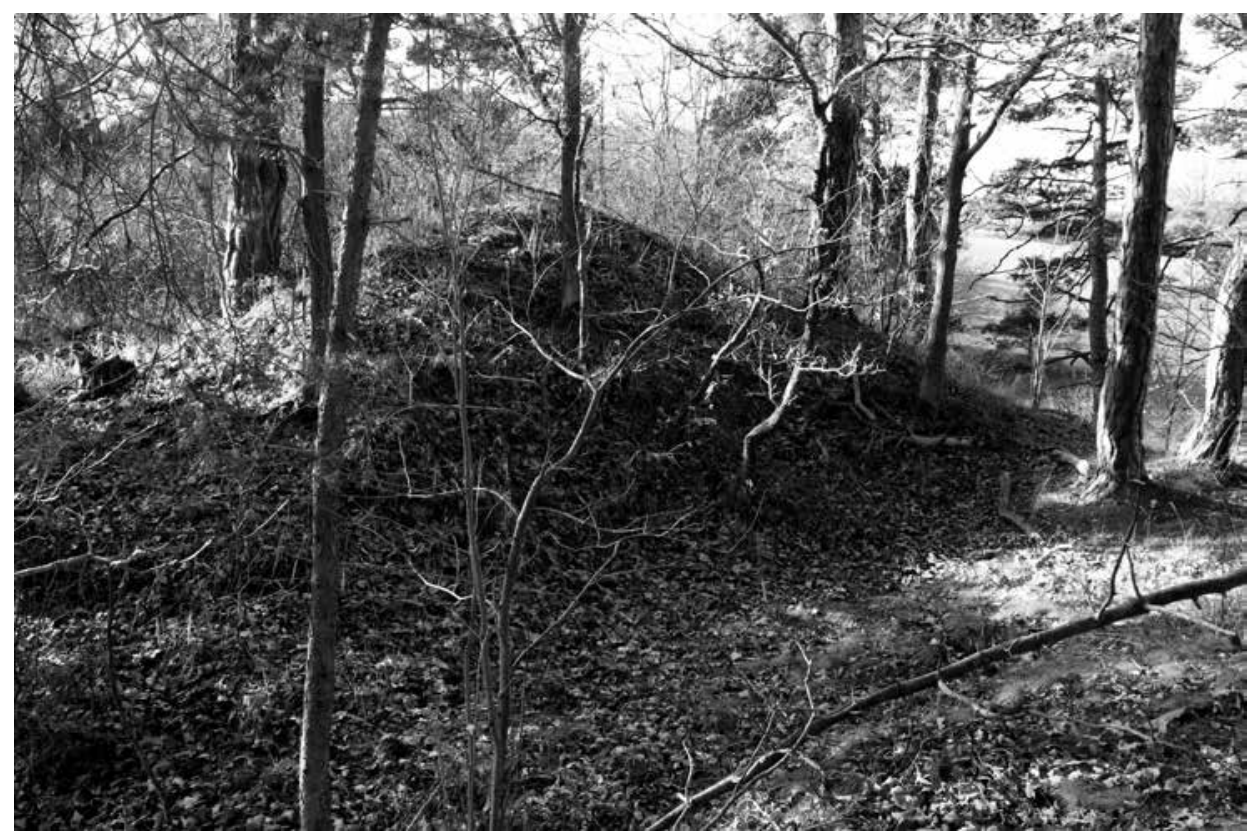

Obr. 7. Borovany u Bernartic, okr. Písek. Opevněné sídlo 1, pohled na vnější př́íkop a centrální vyvýšenou část lokality ze severu. Foto J. Hložek.

Abb. 7. Borovany u Bernartic, Bez. Písek. Befestigter Sitz 1, Blick auf den Außengraben und den zentralen, höher liegenden Teil der Fundstelle von Norden. Foto J. Hložek.

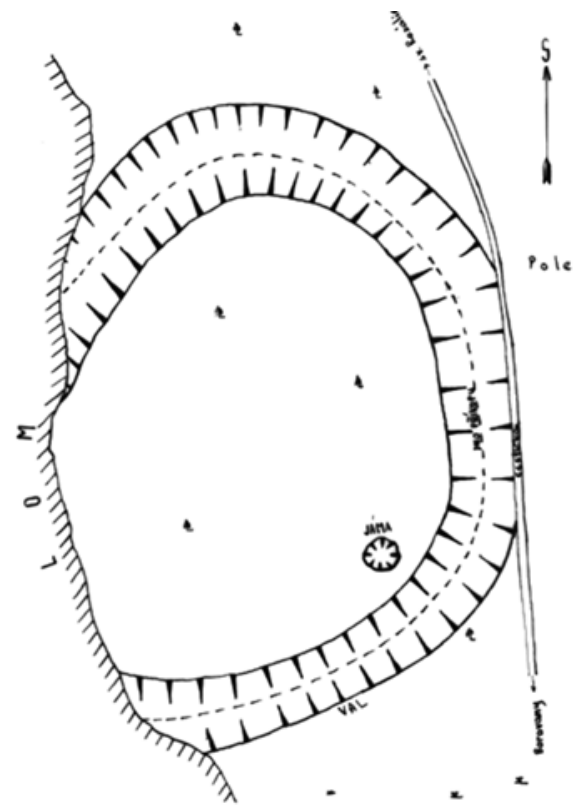

Obr. 8. Borovany u Bernartic, okr. Písek. Terénní náčrt opevněného areálu 2 bez grafického měřítka. Podle Michálek 1965, obr. 2.

Abb. 8. Borovany u Bernartic, Bez. Písek. Geländeskizze des befestigten Areals 2 ohne graphischen Maßstab. Nach Michálek 1965, Abb. 2. jící jeho překonání. Avšak tento násep je možné považovat za mladší úpravu, vytvořenou po zániku mostu přes př́íkop, a nesouvisí tak s původním komunikačním schématem lokality, ale až s novověkým využitím tohoto prostoru. Koruna valového tělesa vykazuje zejména $\mathrm{v}$ jihozápadní části svého průběhu výrazné nepravidelnosti, které je možné přičítat nejen vzniku mladšího náspu překonávajícího př́kop, ale také např. vývratům či dalšímu novověkému využití lokality. Téměř celá západní část objektu byla poškozena novověkým lámáním kamene. V lomové stěně je dodnes patrná slabá šedočerná kulturní vrstva tvořená převážně nečistotami z doby života fortifikace překrytá mladším splachovým souvrstvím. Vnitřní opevněná plocha se mírně svažuje směrem k západu a vyjma jediného zahloubeného objektu nevykazuje stopy zástavby ani dalšího členění. Vnitřní obvod opevněného areálu je tvořen ostrou terénní hranou, která nevykazuje stopy původního opevnění nebo jiného způsobu vymezení. S ohledem na četné analogické situace $\mathrm{z}$ kontextu opevněných objektů založených ve 13. a 14. století je možné předpokládat patu vnitřního opevnění pod 


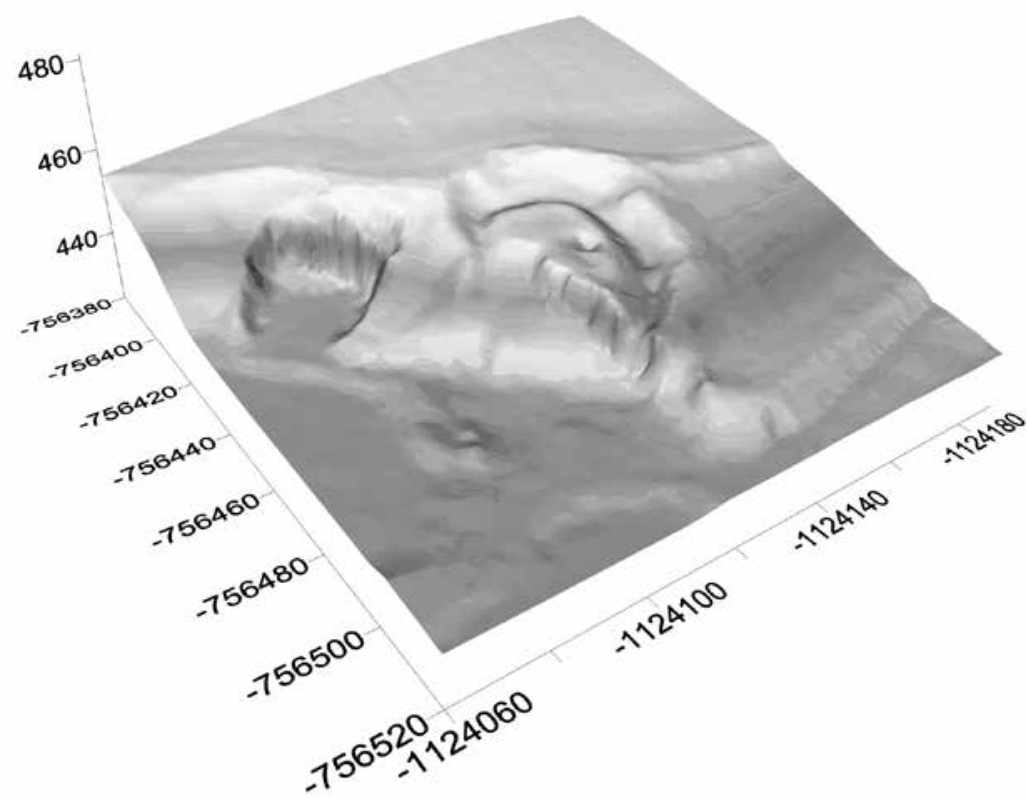

Obr. 9. Borovany u Bernartic, okr. Písek. Vizualizace opevněného sídla 2 na základě Digitálního modelu terénu 5. generace DMR5G. Vytvořil P. Menšík v programu Surfer 10.

Abb. 9. Borovany u Bernartic, Bez. Písek. Visualisierung des befestigten Sitzes 2 nach der Vorlage eines sog. Digitalen Geländemodells der 5. Generation DMR5G. Erstellt von P. Menšík mit der Software Surfer 10.

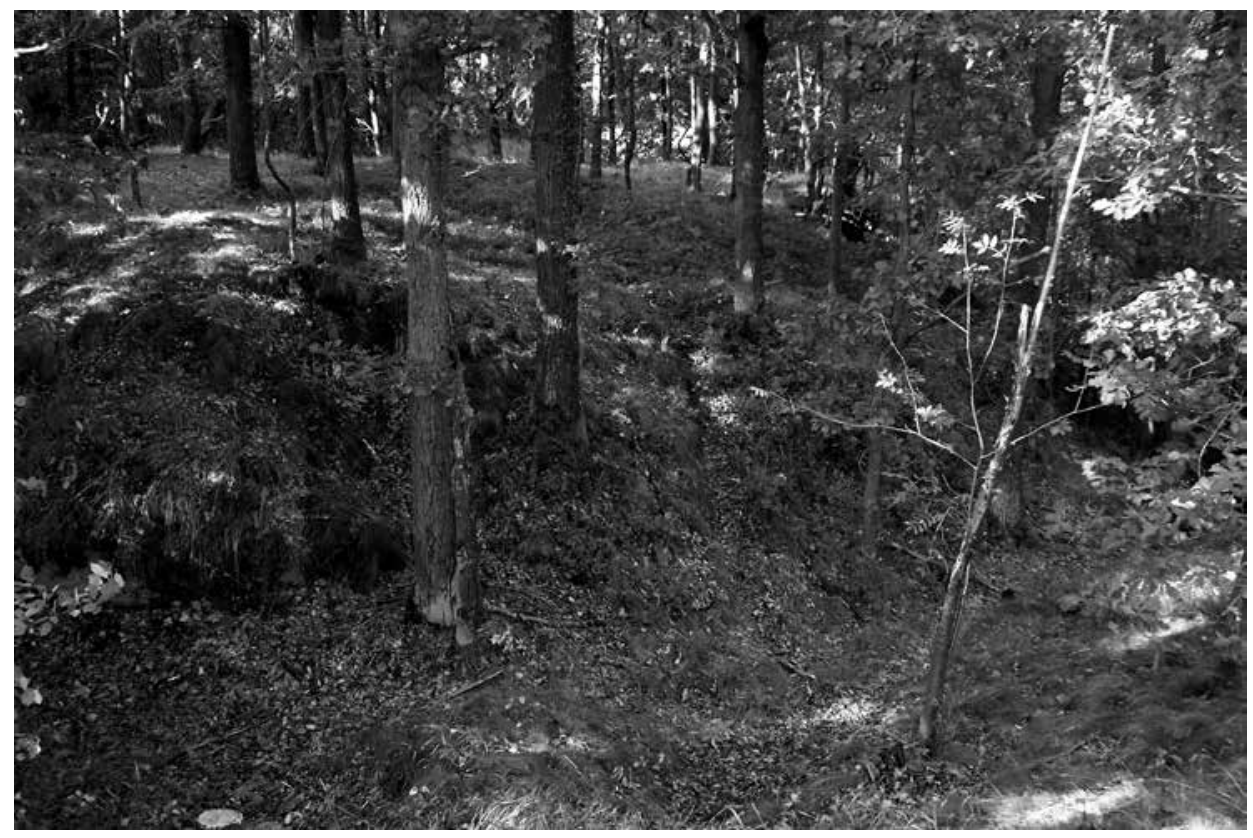

Obr. 10. Borovany u Bernartic, okr. Písek. Opevněného sídlo 2, pohled na vnější př́íkop a centrální vyvýšenou část lokality. Pohled ze severu. Foto P. Menšík.

Abb. 10. Borovany u Bernartic, Bez. Písek. Befestigter Sitz 2, Blick auf den Außengraben und den zentralen, höher liegenden Teil der Fundstelle von Norden. Foto P. Menšík. 
vnější hranou vnitřní opevněné plochy, ve svahu obvodového prŕíkopu. Za tohoto předpokladu by byly pozůstatky základových partií obvodové fortifikace v podobě např́klad nasucho kladené obvodové hradby nebo kamenné podezdívky překryty erozním souvrstvím. Na povrchu dna př́ikopu však nejsou patrné podstatnější pozůstatky kamenné destrukce, která by hovořila ve prospěch předpokladu existence fortifikace vystavěné za použití většího množství kamene. Vyloučit pak není možné ani dřevěnou podobu vnitřní fortifikační linie. S ohledem na celkový stav lokality je ovšem zřejmé, že její současná podoba je výsledkem působení širokého spektra archeologických transformací (k této problematice souhrnně Neustupný 2007, 46-64).

Opevněnému areálu dominovala pravoúhlá podsklepená samostatně stojící, nejspíše věžovitá stavba dochovaná v podobě pozůstatků suterénu o rozměrech ca $4 \times 5$ metrů. Stavba, jejíž byl suterén součástí, byla založena $\mathrm{v}$ jižní části vnitřní opevněné plochy mimo kontakt $\mathrm{s}$ obvodovým opevněním. S ohledem na mladší využití zaniklého suterénu trampy, zejména jeho částečné vyklizení a další terénní úpravy, není možné rekonstruovat místo někdejšího vstupu. V prostoru zaniklého suterénu se však i přes mladší úpravy a využití nachází větší množství lomového kamene, který by mohl představovat pozůstatek vnitřní kamenné plenty či podezdívky. Ovšem tuto domněnku by mohl ověřit pouze archeologický odkryv. Předpokládáme-li vedení př́ístupové komunikace od východu přes nejmohutnějši partie obvodové fortifikace, byla by tato patrně centrální stavba opevněné lokality vystavěna $\mathrm{v}$ její lépe chráněné části. $\mathrm{S}$ ohledem na poškození nejlépe přírodními podmínkami chráněné západní části lokality novověkým lomem však není rekonstrukce plného rozsahu zástavby opevněného areálu možná. Lze ovšem předpokládat, že značná část zástavby opevněné plochy byla tvořena nadzemními stavbami vystavěnými především za použití dřevěných, nebo dřevohlinitých konstrukcí. Doposud na lokalitě nalezený keramický materiál je možné datovat do poloviny 13. století. Nejrozsáhlejší keramický soubor byl v minulosti získán z lomem narušené sídlištní vrstvy v západní části opevněné lokality (Michálek 1973; 1975, 9; Fröhlich 1975, 9). Starší nálezy, pokud nějaké byly učiněny, jsou dnes nezvěstné. Soubor keramiky získaný na lokalitě v roce 2014, tvořený čtyřmi zlomky nezdobených výdutí nejspíše hrncovitých nádob, plně zapadá svým charakterem do průběhu druhé poloviny 13 . století.

\section{Archeologické a historické prameny}

Referované lokality jsou často zmiňovány v celé řadě regionálních prací (Chleborád 1928, 280; Kytka 1940, 199; Fröhlich-Michálek 1978, 113; Fröhlich 1997, 10). Samostatné informace o opevněných sídlech i samých Bernarticích podává regionální badatel F. Lískovec (1943, 3-15):

Vneděli 30. května 1943 do Veselíčka - Bernartic - Sv. Rosalie - Borovan - Soví - Bláto Bechyně

(...) z Borovan vyšel jsem na jih dlouhou ulici a dal jsem se cestou vlevo (vpravo odbočuje silnice do Bílinky, blizké vesnice) a as po 5 min. tam kde vlevo je veliký lom a na protější straně nad potokem stoji smirči křžž, jehož levé rameno je uraženo. K němu se připojuje dole z ploché ruly klekátko. Nápis ani vročení na něm není. Byly-li nějaké symboly, jsou otlučeny. Kř́ž stojí na kopečku, jako na nějakém hromadném hrobu. U křiže jsem se zastavil ve 3/4 9 hod. Takový kř́ž prý je i na jv. vrchu zvaného „Na Posvátném“, tedy na straně druhé. Tam jsem již nezašel, abych jej vyhledal.

Pokračoval jsem polní cestou nad potokem Borovanským, který se vine pěkným lučinatým údolím pod vesničkou Bílinkou, a brzy potom jsem vešel do lesa. Pátral jsem po obou stranách po mohylách, ale nenalezl jich. Najednou se po zahnutí na konci lesa objevila přede mnou stavba malého kostelika, kaple sv. Rosálie, se dvěma chalupami v bezprostřední blizkosti.

Pod kaplí je studánka a nad ní výklenek, v němž je oltářik se slušnou sochou ležící sv. Rosálie, na stranách dvě polychromované sochy. Voda byla trochu podkalená.

1 Vypsány pouze informace týkající se Bernartic a referovaných tvrzí. Celý text př́spěvku se nachází na s. 1-23. 
Kolem kostelika, do něhož jsem se laskavostí pravého chalupníka dostal, je morový hřbitov, dosti veliký, nebot' zde prý v r. 1772-1773 pochováno na 700 osob z daleka široka. Na kosteliku je znát troji stavebni obdobi. Apsida polokruhová a podlouhlá je prvé obdobi z r. 1682, II. obdobi z r. 1719 a třetí z r. 1835.

Ke kosteliku začaly se konat pouti, potom uzavřen, poněvadž posviceni se konala $i v$ dobách několikaletého moru, ale na konec přec jen otevren.

Hlavni pout'se koná v červenci. Uvnitř kostelika je pozoruhodná jen křižová klenba, která však je as papírový tisk, na plátně nalepený. O vzniku kapličky panuje pověst, voda pod jeskyní je prý léčebná, tj. zázračná (...). Hřbitov morový ohraničuje plot, kterýje vrouben lipami, z nichž dvě jsou opravdu mohutné (3 1/2 metru v objemu).

Sháněl jsem se po mohylách a tu obyvatel z jedné té chalupy mi ř́kal, že nad druhouvlastně pod druhou chalupou jsou kopce. Kolem chalupy, která je téměr v lese, vešel jsem do lesa „V mladém“ ř́dký borový les a našel úhrnem 5 roztroušených mohyl, vesměs nakopaných.

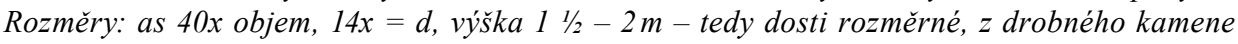
a zemé nasypané.

Od poslední mohyly zavedl mě občan až na konec ostrohu, abych prý viděl na „Hrádek“, po kterém jsem se ptal. Pod sebou jsem viděl potok v hlubokém údolí, který prý býval velikou vodni přehradou a obléval tvrz Hrádek, ale jenom na dvou stranách. Misto hráze přehrady, je dnes jen prechod přes údolí-brlení.

Vrátili jsme se zpět ke kapli a po připojeni druhého souseda šli jsme cestou k Borovanům, ale brzy jsme odbočili vpravo, šli po pokraji lesa a poli nad strání. Brzy jsem uviděl v ř́dkém lese ostroh, na jehož konci je kruhové městiště býv. tvrze Hrádku.

Městiště dosti veliké (snad obvod na 200x) je obehnáno hlubokým př́kopem, valy a u jedné strany je prohlubeň jako po baště, v níż je náznak po studni nebo po hladomorně.

Dle popisů prý proti této tvrzi, kostelíku bližši, byla druhá tvrz. Kde však, není udáno. Snad na onom ostrohu, kam jsem zašel prvně. Někde jsem četl, že si hleděli obyvatelé těchto tvrzí do oken.

Pod tvrzi brzy se vlévá Borovanský potok do Borovanského rybnika, po jehož východním břehu je rozložena nevelká ves Borovany.

Pod hradištěm je chalupa. V Kytkovi (str. 206) takto je psáno o tvrzích. V mistech, kde ústi potok Borovanský, býval dřive jiný rybnik, zvaný Hrádek, dnes však již vysušený. Po obou stranách rybnika na př̉krých stránich stálo po jedné tvrzi. Tvrz menši na z. straně a bližši ke kosteliku stála Hrádek a vypínala se na ostré skalni výspě, ze tři stran obklopená vodami rybníka Hradeckého.

$\mathrm{Na}$ 4. straně k severu byl hluboký přikop a vysoký val z části dosud zachovaný. Ježto tvrziště má rozměry asi $15 \mathrm{~m}$ délky a $6 \mathrm{~m}$ šǐrky, dá se souditi, že hrádek musel býti opravdu malý a že obsahoval asi jenom věž a malé staveni nebo dvorek.

Kusy cihel, škváry a popel zde před časem vykopané potvrzuji, že hrádek kdysi shořel. Dle tvaru tvrze možno tvrditi, že byla založena bud' ve XIII. st. nebo nejpozději ve XIV. st. Avšak již ve XVI. st. bylo tvrziště zarostlé lesem a řikalo se této výšině a rybníku již tehdy na Hrádku.

Na druhé straně rybnika nad samotou, zvanou Hradecký, stávala druhá tvrz. Na straně z. byla chráněna rybnikem, na ostatnich stranách byla obehnána hlubokým a širokým přikopem, opevněným dřevěnou ohradou. Délka tvrze $25 \mathrm{~m}$, šiřka $15 \mathrm{~m}$. Na vyšši části tvrziště stávala asi věž.

Tretí tvrz, hlavní, stávala nad rybnikem Borovanským, kde se nyni prostírá ves. Tvrz byla zbořena teprve r. 1867, když staveni s celým statkem vyhořelo.

Bylo postaveno o dvou poschodich, kryté dvěma spolu spojenými střechami. V prízemí bývala klenutá sýpka, v I. patře komora a 2 světničky, ve II. patře pak 3 světnice a komora. Zde sídlila rodina zemanská. Když byly zdi po požáru bourány, kladlo zdivo velký odpor svoji pevností. Tehdy byla pobořena i staveni bývalého dvora a pivovaru. Při bourání zdi byl objeven výklenek uvnitř zdiva, kde byla nalezena zazděná lidská kostra. (...) 
O větším „tvrzišti“ severozápadně od obce Borovany nad stavením čp. 38 se zmiňují také A. Beneš a J. Michálek (Beneš 1964, 10; Michálek 1965; 1967, 53), kteří společně v roce 1962 zaznamenali v místě porušeném lomem několik středověkých objektů, v nichž byly nalezeny keramické zlomky z 13. století. ${ }^{2}$ Další průzkum na lokalitě provedl A. Beneš v roce 1969, přičemž nalezl vrcholně středověkou keramiku a zlomek mazanice (Michálek 1973). ${ }^{3}$ Následoval povrchový průzkum J. Fröhlicha v roce 1971, který objevil v profilu lomu u ,většího tvrziště“ zlomky středověké keramiky a mazanice a uhlíky (Fröhlich 1975, 9), ${ }^{4} \mathrm{v}$ místě menšího, severněji položeného „tvrziště“ pak středověké střepy, strusku, mazanici, kůstku, uhlíky, železnou skobu (?) a železný hřebík (Fröhlich 1975, 9-10, tab. 18:4-5).

O dějinách Bernartic a Borovan pojednal obsáhle ve svém díle A. Sedláček (1996, 45-51). Zpracovat obšírnější popis soudobé majetkoprávní situace $\mathrm{v}$ tomto regionu je prakticky nemožné, a to $\mathrm{z}$ toho důvodu, že A. Sedláček se aktivně účastnil generálního zařizování paarských archivů v Bechyni a celý fond správy velkostatku Opařany zpracoval v archivní těleso. Tento fond utrpěl velké ztráty zejména $\mathrm{v}$ otázkách staršího materiálu, a to $\mathrm{z}$ důvodu přechodu Bernartic v roce 1691 do majetku jezuitů. Po zrušení řádu papežem roku 1773 přešly statky Bernartice a Borovany pod správu c. k. administrace komorních statků. Velmi neblaze se v těchto souvislostech zapsal patronátní komisař Halbiger spravující velkostatek Opařany, kam Bernartice s Borovany správně náležely, který ve snaze zakrýt rozsáhlé defraudace zinscenoval požár archivu, aby se zbavil usvědčujících dokumentů (Haubertová 1959, 8). Mnoho materiálu, který by umožnil přesnější rekonstrukci historického vývoje sledované oblasti, tak bylo zničeno.

První popis obou „tvrzišt'“ nalezneme v díle Hrady, zámky a tvrze královstvi Českého (Sedláček 1890, 45-51), z jehož informací čerpají i všechny následující práce (např. Kytka 1940; Mikolášek 2001). A. Sedláček přináší popis obou lokalit a nabízí i možnou hypotézu historického vývoje $(1890,49)$. Vznik obou „tvrzišt'“ podle něj může souviset s dělením otcovského majetku za Konráda z Bernartic, který svým synům Buzkovi a Petrovi daroval Borovany s př́íslušenstvím, „a že si každý z nich tvrz při Borovanech postavil, aby blizko sebe bydlice, také po bratrsku spolu se pobaviti mohli“ (Sedláček 1890, 49). Po důsledném průzkumu lokalit je však nutno konstatovat, že tato hypotéza je vzhledem k charakteru terénních reliktů neudržitelná.

Bernartice a Borovany jsou velmi starobylými lokalitami, které do psané historie vstupují v průběhu 13. století. Starší je zmínka o Borovanech, pochází z roku 1219, a to v souvislosti s darováním vsi Bojenice u Bernartic milevskému klášteru králem Přemyslem Otakarem I. (CDB II, 174 č. 188). V roce 1293 se uvádí Bernart z Bernartic (FRA 23, 55-56 č. 52), který zde, dle všeobecného mínění, založil městečko a vystavěl tvrz. Někde se uvádí, že páni z Bernartic se připomínají již roku 1125 jako vedlejší větev Vítkovců (Kytka 1940, 199). Již výše zmiňovaná listina z roku 1293 staví pány z Bernartic do světla příbuzenství s Jindřichem z Kosové hory, ale takto časnou zmínku kladenou do počátku 12. století nelze pramenně podložit. Jisté však je, že místo bylo nejpozději na počátku 13. století osídleno, čehož je svědkem bernartický farní kostel sv. Martina.

Z roku 1251 pochází zmínka z Letopisů českých o bernartickém faráři Martinovi, který byl zajat a uvržen do vězení, a následně po propuštění podal žalobu na opata milevského, pročež na všechny kostely tohoto kláštera byl uložen interdikt (FRB II, 288-289). Kostel sv. Martina je románského původu, více o jeho dataci napověděl stavebně historický průzkum, který v současné stavbě odhalil dvě románské stavební etapy (Varhaník 1993, 122). Původně šlo o prostou jednolodní stavbu krytou sedlovou střechou. Kostel byl v první fázi bezvěžový. Stavba věže následovala v nevelkém časovém odstupu od stavby lodi. Ve spáře mezi zdivem štítu a věže se dochovaly pozůstatky původního zastř̌š̌ní lodi v podobě zbytků třiceti stř̌ešních latí. Dendrochronologické datování vložilo smýcení dřeva do let 1222-1223 (Kyncl-Varhaník 2010, 369-372). Nález byl

2 Z průzkumu A. Beneše a J. Michálka ze dne 13. 6. 1962 pochází celkem devět publikovaných keramických zlomků ze 13. století, které jsou uloženy v Prácheňském muzeu v Písku pod inv. č. P 1140.

3 Nálezy jsou uloženy v Západočeském muzeu v Plzni pod př́r. č. P 9/69. V archivu ARÚ AV ČR, Praha, v. v. i., jsou uloženy také fotografie F00041991-F00041994 z roku 1969 od A. Beneše.

4 Nálezy z tvrziště jsou uloženy v Prácheňském muzeu v Písku pod inv. č. 1723. 
o to zajímavější, že dokazuje, že lod' byla zastřešena taškovou krytinou (Varhaník 1993, 123), která byla zřejmě vyráběna v nedalekém milevském klášteře, kde byla roku 1972 archeologicky zkoumána zaniklá cihelna datovaná do 13. století (Drda 1983). Samozřejmě tato souvislost plně neřeší otázku vzniku zmíněné sakrální stavby. V této oblasti se zejména v průběhu 13. století střetávaly mocenské ambice světských rodů, jakými byli především Vítkovci, a církevních institucí, které zde zastupoval milevský klášter. O tom, že kostel v Bernarticích vystavěla hut' premonstrátského milevského kláštera, dosavadní literatura sice nepochybuje (Mencl 1958, 135; Kuthan 1977, 182-183), ale naši otázku týkající se osoby zakladatele obou sledovaných opevněných objektů nikterak spolehlivě neřeší.

Páni z Bernartic drželi toto zboží do počátku 80. let 14. století, kdy je kupuje Konrád z Chvojna, který se roku 1383 honosí predikátem z Bernartic (RT I, 482). Dva z jeho synů prokazatelně seděli na borovanském i bernartickém zboží (Sedláček 1890, 47). Podle A. Sedláčka měly tedy v této době vzniknout obě „tvrze“ v blízkosti Borovan, nebot' Borovany figurují v predikátech obou bratrů. Po krátkém intermezzu, kdy zboží zřejmě držela Markéta z Čestic, přešlo do rukou Mikuláše Krchlebce z Krchleb, jehož dcery prodaly Bernartice Rynartovi z Dubu, který je držel do roku 1477, kdy je kupuje Burian z Lažan a Bechyně. ${ }^{5}$ Majetkové poměry, jak se zdá, byly poněkud složitější, statek Bernartice byl rozdělen přinejmenším na dva díly, protože roku 1510 se na Bernarticích připomíná Eva z Čestic ${ }^{6}$ a z dob pozdějších jsou dochovány smlouvy o dělení statku - tak jako roku 1553, kdy je zmiňována tvrz přímo v Bernarticích, ale v Borovanech žádná tvrz uváděna není, pouze poplužní dvůr.7 Bechyňští zboží roku 1604 prodali Anně Puchfelderové ze Starého Města pražského, která je za dva roky prodává jezuitské koleji sv. Klimenta na Starém Městě pražském. ${ }^{8}$

\section{Závěr a diskuse}

Jak dokládají prozatím nečetné archeologické nálezy z prostoru obou opevněných lokalit, je možné datovat jejich vznik a rámcově také období jejich života do doby kolem poloviny 13. století, tedy do doby hluboko před prvními písemnými prameny zachycujícími dělení majetku Konráda z Chvojna a Bernartic. Zaměříme-li se pak na oba opevněné objekty a prostor jejich bezprostředního zázemí, je zrejemé, že obě lokality jsou součástí krajiny dlouhodobě utvářené zejména těžební činností. Cílem zde však nebyl jen stavební kámen, jehož těžba v období novověku je dodnes patrná ve stěnách údolí Bílinského potoka, ale také možná prospekce ložisek polymetalických rud a dostupných zdrojů železné rudy v podobě tzv. bahenních rud tvořených biogenními limonity vznikajícími $\mathrm{v}$ teplých močálovitých vodách, nap̌r. $\mathrm{v}$ širokých potočních nivách. Pokusy o zpracování těchto rud indikují především starší nálezy strusky z prostoru mezi oběma objekty i ze samé lokality „Na hrádku“.

Na základě dosavadního stavu poznání obou lokalit, doplněného o nově získané informace, je tak možný nástin interpretace obou, na dohled vzdálených opevněných lokalit coby možných opěrných bodů významného milevského kláštera na nově získaných a následně kolonizovaných územích, kde cílem kolonizačních snah bylo nejen osvojení, kultivace a osídlení nových částí klášterního dominia, ale také prospekce $\mathrm{s}$ cílem využití surovinových zdrojů $\mathrm{v}$ této oblasti a jejich ochrany. S ohledem na absenci písemných pramenů, které by ilustrovaly majetkoprávní poměry $\mathrm{v}$ této oblasti $\mathrm{v}$ průběhu první poloviny 13. století, však nelze vyloučit ani možnou souvislost obou objektů s kolonizačními snahami mocného a neobyčejně rozvětveného jihočeského rodu Vítkovců (např. Fučíková-Gaži-Lavička a kol. 2011; Šimůnek-Lavička 2011) v místě majetkoprávní hranice s majetky milevského kláštera. Těžba a zpracování rud a drahých kovů se staly významným zdrojem př́ijmů tohoto šlechtického rodu v různých obdobích středověku. $\mathrm{S}$ ohledem na postižení dalších širších souvislostí vzniku obou opevněných lokalit pak nelze

5 SOA Třeboň, Velkostatek Opařany, kart. 1, inv. č. 1, sg. 8/1, 24

6 SOA Třeboň, Velkostatek Opařany, kart. 1, inv. č. 2, sg. 8/1, 25 .

7 SOA Třeboň, Velkostatek Opařany, kart. 1, inv. č. 3 .

8 SOA Třebon̆, Vs Dobronice, kart. 1, inv. č. 10, sg. 8/1, 31. 
opomenout ani možnost pronájmu nově získaného území milevského kláštera světské osobě, která mohla mít zájem na kolonizaci tohoto území. S tímto modelem zacházení s částí majetků se setkáváme také v případě dalších církevních institucí (např. Durdík-Bolina 1996; Novobilský-Rožmberský 2002, 22; Hložek-Křivánek 2008, 307-310).

Z hlediska volby staveniště, charakteru opevnění i možné zástavby se oba objekty nikterak nevymykají z rámce hradů nižší kvalitativní úrovně zakládaných v Čechách zejména v průběhu první poloviny 13. století, které však v době svého života mohly sehrávat poměrně významné funkce (srov. např. Anderle-Švábek 1989; Wolf 1998; Ulrychová 2001; 2006; Hložek 2006). Nemalá skupina těchto objektů pak spadá do kontextu hradů přechodného typu (k širším souvislostem a definici tohoto hradního typu Durdík 2004; 2007; k další diskusi např. Kypta 2008). $\mathrm{S}$ obdobným dispozičním řešením i výběrem staveniště, chráněného $\mathrm{z}$ více stran přírodními překážkami, se můžeme setkat nejen ve většině případů objektů spadajících do širšího kontextu hradů přechodného typu, ale také $\mathrm{v}$ př́ípadě nejstaršího horizontu šlechtických hradů, postavených v románském slohu na našem území, hradů chebských ministeriálů (k této problematice např. Karel-Knoll 2006) či v př́ípadě některých opěrných bodů spojovaných s ochranou těžebních a zpracovatelských areálů na Strašicku (Anderle-Švábek 1989), jakými jsou např. Vimperk (Anderle-Švábek 1989, 113, obr. 5; naposledy Durdík 2007, 222-228), hrad na Radči (AnderleŠvábek 1989, 119, obr. 8; Durdík 2005, 172-173) či hrad na Babské skále (Anderle-Švábek 1989, 120, obr. 9; Durdík 2005, 172). Některé z těchto objektů s ohledem na svou rozlohu a možnou stavební podobu, zejména hrad na Radči či hrad na Babské skále, plně srovnatelné se zaniklou fortifikací v poloze „Na hrádku“ (obr. 4:1, 5:1 a 6), mohly jen stěží plnit funkci rezidenčního objektu. Plně však postačovaly ke kontrole a správě nedalekých těžebních a zpracovatelských areálů. V př́ípadě druhé zaniklé opevněné lokality (obr. 9) je ovšem situace zcela odlišná. S ohledem na svůj plošný rozsah i charakter obvodové fortifikace umožňoval tento objekt rozvoj vnitřní zástavby, která byla minimálně zčásti tvořena podsklepeným, samostatně a mimo linii fortifikace stojícím objektem nejspíše věžovitého charakteru. Značnou podobnost pak vykazuje tento objekt se zaniklým Liškovým hradem, okr. Plzeň-jih (naposledy Hložek a kol. 2013). Oba objekty vznikly prakticky na totožných staveništích, situovaných na výrazných terénních hranách. Nejlépe př́rodními podmínkami chráněná strana těchto objektů byla zajištěna pouze lehčím opevněním. V př́ípadě obou objektů tvořila patrně dominantní prvek jejich zástavby samostatně stojící podsklepená dřevohlinitá stavba nejspíše věžovitého charakteru. Vznik obou opevněných objektů je pak možné pravděpodobně datovat do doby kolem poloviny 13. století. Obdobné stavební podoby pak dosahoval také zaniklý jihočeský hrad Boršov (Durdík 2000, 76) vystavěný na hraně strmého svahu údolí Vltavy, kde však došlo na přístupové straně ke zdvojení čelní části fortifikace.

Přestože zůstává, s ohledem na nemožnost rekonstrukce majetkoprávních poměrů v této oblasti ve 13. století, osoba stavebníka obou opevněných lokalit nejasná, poskytují oba objekty cenné informace o variační šiři stavební spodoby a kvalitativní úrovně nejstaršího horizontu českých hradů. V době jejich vzniku byly na ně ovšem kladeny obdobné nároky jako na organismy nesporně větších a kvalitnějších kamenných hradů vznikajících nejen v kontextu královské, ale také rozvíjející se šlechtické hradní produkce. I přes mnohá nová zjištění týkající se stavební podoby obou opevněných lokalit však zůstává řada interpretací na úrovni více či méně pravděpodobných hypotéz, které nemusí potvrdit ani případný archeologický odkryv. Nicméně od dalšího výzkumu těchto, povětšinou na úrovni terénních reliktů dochovaných hradních lokalit 13. století, vyžadujících systematickou památkovou ochranu a péči, je možné očekávat podstatná zjištění týkající se provozní reality a hmotné kultury nejstarších vrcholně středověkých hradů na našem území. Systematicky koncipovaný archeologický výzkum této kategorie opevněných objektů by se měl stát jednou z priorit současného kastelologického bádání. Takto orientovaný výzkum středověkých opevněných lokalit představuje jednu $\mathrm{z}$ cest směřujících $\mathrm{k}$ uchopení řady klíčových procesů 13. století (napr. Klápště a kol. 1982; Klápště 1994) v celé jejich variační šíři i možnost rekonstrukce někdejšího významu a smyslu vrcholně středověkých opevněných lokalit různé kvalitativní úrovně, stojících doposud v mnoha ohledech mimo hlavní směry sou- 
časného českého kastelologického bádání (srov. např. Wolf 1998; Durdík 2004; 2007; Ulrichová 2001; 2006; Hložek a kol. 2013; Ulrichová v tisku).

Článek vznikl za podpory projektu SGS-2015-059 Západočeské univerzity v Plzni.

\section{Prameny}

FRA 23: Fontes rerum Austriacarum 23. Urkundenbuch der Cistersienserstiftes B. Mariae V. Hohenfurt in Böhmen (Pangerl, M., ed.). Wien 1865.

FRB II: Fontes rerum bohemicarum II (Emler, J., ed.). Praha 1874.

CDB II: Codex diplomaticus regni Bohemiae II (Friedrich, G., ed.). Praha 1912.

RT I: Reliquiae tabularum terrae regni Bohemiae anno MDXLI consumptarum I (Emler, J., ed.). Praha 1870. Státní oblastní archiv Třeboň - Velkostatek Opařany, kart. 1, inv. č. 1-3, 10.

\section{Literatura}

ANDERLE, J.-ŠVÁBEK, V., 1989: Hrady na Strašicku - Pokus o rekonstrukci jejich postavení v životě oblasti před polovinou 14. století - Burgen in Gebiet Strašice - Versuch einer Rekonstruktion ihrer Position im Leben des Gebietes vor der Mitte des 14. Jahrhunderts, CB 1, 105-123.

BENEŠ, A., 1964: Borovany, o. Písek, Bulletin záchranného oddělení 1/1963, 10. Písek, inv. č. P 1140.

DRDA, M., 1983: Cihelna 13. století v Milevsku - Eine Ziegelei aus dem 13. Jahrhundert in Milevsko, AH 8, $167-173$.

DURDÍK, T., 2004: Nálezy z hradů přechodného typu (Hlavačov, Angerbach, Tachov) - Funde aus dem Burgen des Übergangtyps (Hlavačov, Angerbach, Tachov). Castellologica bohemica fontes 1. Praha.

- 2005: Ilustrovaná encyklopedie českých hradů. Dodatky III. Praha.

- 2007: Hrady přechodného typu v Čechách. Praha.

DURDÍK, T.-BOLINA, P., 1996: Hrady pražského biskupství (arcibiskupství) - Die Burgen des Prager Bistums (Erzbistums), AH 21, 291-306.

FRÖHLICH, J., 1975: Bernartice, o. Písek, Výzkumy v Čechách 1971, 9-10.

- 1997: Písecko v zrcadle archeologie. Písek.

FRÖHLICH, J.-MICHÁLEK, J., 1978: Archeologické nemovité památky v okrese Písek, Zprávy československé společnosti archeologické 20, 86-129.

FUČÍKOVÁ, E.-GAŽI, M.-LAVIČKA, R. a kol., 2011: Rožmberkové: rod českých velmožů a jeho cesta dějinami. České Budějovice.

GOJDA, M.-JOHN, J. a kol., 2013: Archeologie a letecké laserové skenování krajiny. Plzeň.

HAUBERTOVÁ, K., 1959: Velkostatek Opařany (1477-1938). Prozatímní inventární seznam, uloženo ve Státním oblastním archivu v Třeboni.

HLOŽEK, J., 2006: Ohlédnutí za tvrzištěm v obci Černý Vůl, okr. Praha-západ - Rückblick auf die Wallanlage der Feste in Černý Vůl (Schwarzer Osch), Bezirk Prag-west, CB 10, 239-244.

HLOŽEK, J.-KŘIVÁNEK, R., 2008: Komplexní nedestruktivní výzkum hradu Liběhradu, okr. Praha-západ - Die komplexe undestruktive Untersuchung der Burg Liběhrad, Bezirk Prag-West, CB 11, 297-312.

HLOŽEK, J. a kol., 2013: Hložek, J.-Baierl, P.-Kasl, F.-Menšík, P.-Procházka, M., Liškův hrad, okr. Plzeň-jih. Nové geodetické zaměření lokality a její hodnocení v kontextu soudobé hradní produkce - Burg Liškův hrad, Bezirk Pilsen-Süd. Neue geodätische Vermessungen der Fundstelle und ihre Auswertung im Kontext der zeitgenössischen Burgenproduktion, AH 38, 399-414.

CHLEBORÁD, A., 1928: Popis okresu bechyňského. Bechyně.

KAREL, T.-KNOLL, V., 2006: Felsbaustellen als ein beeinundreckender Faktor der ministerialenburgen des Egerlandes - Bedrock as a determination element for ministerials' castles in the Cheb region, Castrum Bene 9, 181-200.

KLÁPŠTĚ, J., 1994: Změna. Středověká transformace a její předpoklady - Transformation. La transformation medievale et ses conditions préalables, PA - Supplementum 2, 9-59.

KLÁPŠTĚ, J. a kol., 1982: Klápště, J.-Sláma, J.-Smetánka, Z.-Žemlička, J., Studium středověkého osídlení a archeologie - Die Erforschung mittelalterlicher Besiedlung und die Archäologie. In: Metodologické problémy československé archeologie, 137-141. Praha. 
KUTHAN, J., 1977: Středověká architektura v jižních Čechách do poloviny 13. století. České Budějovice.

KYNCL, T.-VARHANÍK, J., 2010: K datování první etapy výstavby románského kostela sv. Martina v Bernarticích, okr. Písek - Zur Datierung der ersten Bauetappe der romanischen St. Martinkirche in Bernartice, Bezirk Písek, AH 35, 369-372.

KYPTA, J., 2008: O metodě typologického výzkumu hradů (na př́kladu tzv. hradů přechodného typu) - Zur Methode der typologischen Burgenforschung (am Beispiel der sog. Burgen des Übergangstyps), AR LX, $565-610$.

KYTKA, J., 1940: Milevsko a jeho kraj. Turistika, památky, historie. Milevsko.

LÍSKOVEC, F., 1943: Zápisník č. XVI. Františka Lískovce, archeologické a cestopisné poznámky z roku 1943. Rukopis ulož. v Husitském muzeu v Táboře, inv. č. PPLF 160, př́ír. č. 234/84/181.

MENCL, V., 1958: Počátky středověké architektury v jihozápadních Čechách, ZPP 18, 133-146.

MICHÁLEK, J., 1965: Borovany, okr. Písek. Nálezová zpráva 6222/65 ulož. v archivu ARÚ AV ČR, Praha, v. v. i.

- 1967: Borovany, okr. Písek, Bulletin záchranného oddělení 4/1966, 53.

- 1973: Borovany, okr. Písek. Nálezová zpráva 3072/73 ulož. v archivu ARÚ AV ČR, Praha, v. v. i.

MIKOLÁŠEK, F., 2001: Bernartice. Bernartice.

NEUSTUPNÝ, E., 2007: Metoda archeologie. Plzeň.

NOVOBILSKÝ, M.-ROŽMBERSKÝ, P., 2002: Hrad Litice u Plzně. Zapomenuté hrady, tvrze a místa 7. Plzeň.

SEDLÁČEK, A., 1890: Hrady, zámky a tvrze království Českého. Díl sedmý. Písecko. Praha.

ŠIMŮNEK, R.-LAVIČKA, R., 2011: Páni z Rožmberka 1250-1520. Jižní Čechy ve středověku. České Budějovice.

ULRYCHOVÁ, E., 2001: Těšín, o. Železnice, okr. Jičín, Výzkumy v Čechách 1999, 312.

- 2006: Archeologické nálezy z hradů Jičínské kotliny uložené v jičínském muzeu - Archäologische Funde aus den Burgen des Beckens von Jičín, die im Museum der Stadt Jičín bewahrt werden, CB 10, 317-334.

- v tisku: Výšinné polohy Jičínska s nálezy ze 13. století, CB 13.

VARHANÍK, J., 1993: Pozůstatky románského zastř̌šení kostela sv. Martina v Bernarticích, ZPP 53, $122-124$.

WOLF, V., 1998: K problematice tzv. kolonizačních provizorií - Zu den Provisorien der Kolonisierung (Erwägungen über die Fortifikationen und ihre Funktion), CB 6, 107-116.

\section{Zusammenfassung}

\section{Zwei befestigte Objekte bei Bernartice (Bezirk Písek). Zur Frage ihres Bezugs, ihrer Funk- tionsinterpretation und Zusammenhänge}

Die zwei untergegangenen befestigten, oberhalb des Bílinský-Bach-Tals im Kataster der Gemeinde Borovany im Bezirk Písek gegründeten Objekte fallen typologisch in den breiteren Kontext der Übergangsburgen. Die beiden Fundstellen, deren Anfänge aufgrund zahlloser archäologischer Funde in die Zeit um Mitte 13. Jahrhundert gelegt werden können, illustrieren nicht nur ein qualitativ hohes Niveau, sondern auch die Variabilität des ältesten Horizonts hochmittelalterlicher befestigter Objekte. Beide Fundstellen wurden auf der mutmaßlichen eigentumsrechtlichen Grenze zwischen den Besitztümern des Klosters Mühlhausen (Milevsko) und des südböhmischen Adels gegründet, und zwar nicht nur als mögliche Kolonisationsstütze, sondern wahrscheinlich auch als Objekte, die den Abbau und die Weiterverarbeitung der verfügbaren Eisenerze sicherten. Beide Objekte sind offenbar noch im 13. Jahrhundert durch eine Brandkatastrophe utergegangen.

Der vorliegende Beitrag entstand unter Förderung des Projektes SGS-2012-059 der Westböhmischen Universität in Pilsen. 
PhDr. Zlata Gersdorfová, Katedra archeologie Filozofické fakulty Západočeské univerzity v Plzni, Sedláčkova 15, 30614 Plzeň, Česká republika, gersdorf@kar.zcu.cz

PhDr. Josef Hložek, Ph.D., Katedra archeologie Filozofické fakulty Západočeské univerzity v Plzni, Sedláčkova 15, 30614 Plzeň, Česká republika, hlozek@kar.zcu.cz

PhDr. Petr Menšík, Ph.D., Katedra archeologie Filozofické fakulty Západočeské univerzity v Plzni, Sedláčkova 15, 30614 Plzeň, Česká republika,pmensik@kar.zcu.cz

Mgr. Milan Procházka, Katedra archeologie Filozofické fakulty Západočeské univerzity v Plzni, Sedláčkova 15, 30614 Plzeň, Česká republika,mprochi@kar.zcu.cz 
